\title{
Epiphany
}

Journal of transdisciplinary studies

\section{APPLICATION OF AN ECOLOGICAL FRAMEWORK \\ TO CLINICAL PRACTICE WITH ADOLESCENTS: TRANSGENERATIONAL TRANSMISSION OF WAR-RELATED TRAUMA IN BOSNIA AND HERZEGOVINA}

\author{
Assoc. Prof. Dr. Mirsad Serdarević, Applied Clinical Psychology, \\ The Chicago School of Professional Psychology, Southern California \\ Campuses* \\ Dr. Senija Tahirović, Private Practice Psychologist
}

\begin{abstract}
In the period between April 6, 1992 and December 14, 1995, an estimated 102,622 people were found to have died due to war-related causes in armed conflicts in Bosnia and Herzegovina. Of those killed in the war in Bosnia and Herzegovina it is estimated that $54 \%$ were civilians. The war profoundly affected the civilian population, which was subjected to mass killings, the systemic use of rape and sexual violence, and the physical and psychological torture inside concentration camps.

This case study paper has four aims. First, it highlights the complexity and severity of the traumatic psychological effects of the war in Bosnia and Herzegovina on its citizens, including the effects of the war on the generation born during or shortly after the war. Second, the paper proposes a heuristic in the form of a broader theoretical approach; an ecological analysis of human development (Bronfenbrenner, 1989). This approach aims to provide a framework for research and the development of intervention strategies for the adolescent children of adult war survivors who have been affected by war-related trauma. Third, the paper presents a case vignette of an adolescent to demonstrate the application of the ecological framework to clinical practice with adolescents. Finally, we explore how the current cultural, political, and societal realities in Bosnia and Herzegovina affect the population in general and the children of war survivors in particular. The transition from a state of war to peace is a long and continuous process with residual effects of violent conflicts permeating the broader society and its
\end{abstract}

\footnotetext{
* Corresponding author: Assoc. Prof. Dr. Mirsad Serdarević, Applied Clinical Psychology, The Chicago School of Professional Psychology, Southern California Campuses, E-mail: mirsad.serdarevic@gmail.com.
} 
inhabitants, even after the war's official end over 23 years ago. The authors argue that roles of psychologists and other mental health providers should expand beyond traditional focus on intrapsychic problems. Rather, effective treatment strategies should also include recognition of and attenuation of the larger systemic stressors that patients experience on daily basis. This could be accomplished through collaboration among psychologists and patients, patients' families, teachers, and community members, all of whom directly or indirectly affect patients' treatment outcomes.

Keywords: Transgenerational trauma; war-related trauma; ecological framework, psychologist roles; PTSD

\section{INTRODUCTION}

The war in Bosnia and Herzegovina profoundly affected the civilian population, which was subjected to mass killings, systemic use of rape and sexual violence, and physical and psychological torture inside concentration camps. In an effectiveness study of U.S.-based Bosnian refugees who experienced multiple forms of trauma, it was shown that the sources of trauma included civil war, combat exposure, loss of loved ones, bombings, with nearly two-thirds of respondents also reporting torture (Schulz, Resick, Huber, \& Griffith, 2006). Further, a strong association was demonstrated between psychiatric disorders (depression and posttraumatic stress disorder [PTSD]) and disability among Bosnian refugees, both upon initial assessment (Mollica, et al., 1999) and upon follow-up (Mollica et al., 2001).

The war in Bosnia and Herzegovina was characterized by the use of extreme violence against civilians (Mrvic-Petrovic, 2001). The psychological effects of trauma are expected to be more severe if the exposure to trauma and traumatic events were prolonged (e.g., Herman, 1997), consistently endured, and included several different sources of trauma including death, proximity to death, rape and sexual violence and proximity to rape and sexual violence, and concentration camp imprisonment, along with familial proximity to those imprisoned in concentration camps.

In the period between April 6, 1992 and December 14, 1995, an estimated 102,622 people were found to have died due to war-related causes in armed 
conflicts in Bosnia and Herzegovina (Tabeau \& Bijak, 2005). Of those killed in the war, it is estimated that 54\% were civilians (Tabeau \& Bijak, 2005). Further, the war was marked by the systematic use of sexual violence and rape (Skjelsbæk, 2006). In addition to the above documentation, attempts to estimate the number of these crimes have also been made (e.g., CID, 2002; Meznaric, 1994). According to Meznaric (1994, p. 92) there is general agreement on the following points:

- there were at least several thousand victims of mass rape;

- many rape victims were young girls between the ages of seven and fourteen;

- rape was often committed in the presence of the victim's parents or children;

- the rape victim was raped by several assailants (Meznaric, 1994, p. 92).

Skjelsbæk (2006) notes that extant "research literature on these crimes emphasizes that sexual violence was carried out in order to humiliate, or destroy, the identity of the victim, and that this was the way in which the violence constituted a weapon of war" (e.g., Allen, 1996; Gutman,1993; Nikolic-Ristanovic, 2000; Stiglmayer, 1994, as cited in Skjelsbæk, 2006, p. 375).

It is important to emphasize that the transition from a state of war to a state of peace is a continuous process, and even though the war in Bosnia and Herzegovina officially ended on December 14, 1995, the residual effects of violent conflicts are expected to permeate the broader society long after the war's official end. Demeny (2011) argues that the aftermath of a violent conflict such as that in Bosnia and Herzegovina not only affects individuals, families, households, and their proximal or distal sociocultural environment during the war, but also, for a period after the war-impacts a society's political context, power relations, and the civilian population's socioeconomic situation. For example, Oberschall (2000) proposes the concept of a cognitive frame to explain that ethnic relations in postwar Bosnia and Herzegovina, while mostly operating under a cooperative frame, are also influenced by and based on memories from the Balkan wars, which the elites use to spread ethnic hatred, insecurity, and fear, all of which activates a crisis frame. It could be argued that, on a broader societal level, such an anxiety-inducing atmosphere could have negative effects on a population 
in general and on survivors of war-related trauma in particular. This is an important factor to consider when evaluating parent-child dyads of parents with war-related PTSD and their children, as the parent-child dyad may be one in a constellation of causes of distress in children and adolescents in postwar Bosnia and Herzegovina.

This case study has four aims. First, it highlights the complexity and severity of the traumatic psychological effects of the war in Bosnia and Herzegovina on its citizens, including the effects of the war on the generation born during or shortly after the war. Second, the paper proposes a heuristic in the form of a broader theoretical approach; an ecological analysis of human development (Bronfenbrenner, 1989). This approach aims to provide a framework for research and the development of intervention strategies for the adolescent children of adult war survivors who have been affected by war-related trauma. Third, the paper presents a case vignette of an adolescent to demonstrate the application of the ecological framework to clinical practice with adolescents. Finally, we explore how the current cultural, political, and societal realities in Bosnia and Herzegovina affect the population in general and the children of war survivors in particular. The transition from a state of war to peace is a long and continuous process with the residual effect of violent conflicts permeating the broader society and its inhabitants, even after the war's official end over 23 years ago.

\section{The Ecological Model}

Studying the experiences of adult war survivors and their children requires a heuristic in the form of a broader theoretical approach. In this review study, we thus selected the ecological analysis of human development (Bronfenbrenner, 1989) (see Figure 1) to inform our arguments. Bronfenbrenner's (1989) ecological model states that individuals are embedded within multiple levels of ecology, with each ecological level exerting influence on the individual's development, while the individual may be empowered to exert his or her own influence on various levels of ecology, a concept better understood as bidirectionality. The following levels of ecology make up Bronfenbrenner's framework: the individual, the microsystem, the mesosystem, the exosystem, the macrosystem, and the chronosystem. Bidirectionality refers to the environment-individual dynamics that involve the individual's abilities to exert influence on the 
environment, while the environment also exerts influence on developing an individual. The ecological model has been argued as an optimal systems approach that allows conceptualization and responses to trauma at the individual, family, community and societal levels (e.g., Awad, Kia-Keating, and Amer, 2019; Hoffman and Kruczek, 2011). To authors' knowledge, no such approach has been used in Bosnia and Herzegovina in provision of mental health services.

The microsystem consists of individuals (e.g., parents, teachers) and communities (e.g., school) with whom the individual comes into direct contact. Much of an adolescent's daily experiences occur within the microsystem.

The mesosystem represents the quality of relationships in an individual adolescent's microsystems, but does not include the adolescent. For example, the relationship between an adolescent's parents would be considered on the mesosystemic level of an adolescent's ecology.

The exosystem consists of one or more interconnected settings in which the individual is not directly involved, but which have an effect on an individual (e.g., state policies that determine funding for mental health services, school enhancement, or prevention programs). For example, an adolescent may not have access to mental health services at school as a result of public health policy.

The macrosystem represents society's social blueprint and consists of cultural norms, values, and social structures. For example, macrosystemic factors may include Bosnians' beliefs about the political system and its ability to bring about positive change, or distrust of opposing political views tied to wartime politics.

Finally, the chronosystem represents the development of relationships among individuals and their environments over time (e.g., historical eras; political relations) (Serdarevic \& Chronister, 2005). 
Figure 1. Ecological model (Bronfenbrenner, 1989).



Note: Chronosystem, which represents change over time, is not represented in the figure. 


\section{Extant Literature on the Transgenerational Transition of War- Related Trauma}

The transgenerational transition of war-related trauma has been explored in the past with regard to Vietnam veterans and their children. For example, in the study conducted by Rosenheck and Fontana (1998), children of Vietnam veterans with PTSD have shown to be at a higher risk for behavioral, academic, and interpersonal problems. According to the study, compared to children of non-combat Vietnam era veterans who do not have PTSD, the children of veterans with PTSD are perceived to be more depressed, anxious, aggressive, hyperactive, and delinquent by their parents. Further, the children of veterans with PTSD are perceived to have difficulty establishing and maintaining friendships. According to the authors, family discord and dysfunction can make it challenging for adolescents to establish positive attachments to parents, making it difficult for children to create healthy relationships outside the family. Finally, additional research indicates that children may have particular behavioral disturbances if their veteran parent participated in abusive violence (i.e., atrocities) during their combat service (Rosenheck \& Fontana, 1998).

Veterans with PTSD have been shown to have similar effects on adolescent children as they do on younger children (Dansby \& Marinelli, 1999). Compared to adolescents whose fathers were not veterans, adolescents whose fathers served in combat roles in Vietnam showed more negative attitudes toward their fathers, poorer attitudes toward school, lower scores on creativity, and higher levels of depression and anxiety (Dansby \& Marinelli, 1999).

These findings serve as a key reminder that it is important to not only target our interventions on individual adolescent children, but, ideally, on the entire family. Further, given the complex societal effects on adolescents whose parents suffer from PTSD, it is important to propose, informed by the ecological model, an overarching prevention, advocacy, and psychological treatment approach to the treatment of PTSD for both parents with PTSD and children/adolescents of parents with PTSD. Suggestions for such an overarching intervention approach are summarized in Table 1. Rather than focusing intervention on one level of ecology, the model encourages engagement with educators and policy makers to assure better treatment opportunities and reduce factors that may contribute to the retraumatization 
of individuals and their children (e.g., TV news format and the emphasis on coverage of aggressive politicians with covertly violent messages).

According to the fifth edition of the Diagnostic and Statistical Manual of Mental health Disorders (DSM-5), for children aged seven years old and older, PTSD diagnostic criteria include four clusters of symptoms that emerge following exposure to various traumatic events. Our focus is on a child's learning about the traumatic event(s) occurred to a parent(s) or caregiving figure, child exposure to a parent's PTSD symptomatology (e.g., irritability, anger, impulsive behaviors, increased arousal), and societal contributions to a child's belief that the world is not safe (as a consequence of both the home environment and societal messages).

Table 1. Ecological Model and Corresponding Psychological and Psychoeducation/Advocacy Interventions

\begin{tabular}{|c|c|c|}
\hline Level of Ecology & Type of Stressor & $\begin{array}{l}\text { Treatment, Recommendation, and } \\
\text { Other Strategies (examples) }\end{array}$ \\
\hline $\begin{array}{l}\text { Individual adolescent } \\
\text { (sex; cognitive factors; biological } \\
\text { Mechanisms) }\end{array}$ & $\begin{array}{l}\text { Genetic predisposition to anxiety; } \\
\text { cognitive vulnerability to anxiety. }\end{array}$ & $\begin{array}{l}\text { Psychoeducation about PTSD; } \\
\text { relaxation, calming, and coping skills; } \\
\text { cognitive processing of reactions to } \\
\text { trauma; affect monitoring and emotion } \\
\text { regulation skills; helping the adolescent } \\
\text { construct a therapeutic trauma } \\
\text { narrative; conjoint parent-child sessions } \\
\text { (Carrion and Kletter, 2012). }\end{array}$ \\
\hline Microsystem & $\begin{array}{l}\text { Family (e.g., father with a PTSD } \\
\text { diagnosis)-angry outbursts toward } \\
\text { adolescent. }\end{array}$ & $\begin{array}{l}\text { Father-adolescent therapy (i.e., conjoint } \\
\text { parent-child sessions). Provide father } \\
\text { with psychoeducation on PTSD and } \\
\text { calming techniques. }\end{array}$ \\
\hline $\begin{array}{l}\text { Mesosystem } \\
\text { (relationships among microsystems) }\end{array}$ & $\begin{array}{l}\text { Interactions between father and mother: } \\
\text { frequent arguments; emotional } \\
\text { distancing. Parental absence or poor } \\
\text { interaction with school and/or teachers. }\end{array}$ & $\begin{array}{l}\text { Family therapy session focused on } \\
\text { processing emotions related to the } \\
\text { father's PTSD, parental discord, and } \\
\text { specific effects on an adolescent. }\end{array}$ \\
\hline Exosystem (public policy) & $\begin{array}{l}\text { Lack of resources in the community; } \\
\text { limited healthcare, etc. }\end{array}$ & $\begin{array}{l}\text { Psychologists, researchers, and } \\
\text { educators serve as advocates for better } \\
\text { healthcare and mental health care. }\end{array}$ \\
\hline $\begin{array}{l}\text { Macrosystem (Culture; SES, Gender } \\
\text { roles, etc.) }\end{array}$ & $\begin{array}{l}\text { TV News and media focused on ethnic } \\
\text { division, and politicians' continued } \\
\text { threats of conflict. }\end{array}$ & $\begin{array}{l}\text { Psychologists, researchers, and } \\
\text { educators serve as consultants to TV } \\
\text { media and educate on the effects of } \\
\text { violent content in the media. Process } \\
\text { emotions in individual or family } \\
\text { therapy related to seeing politicians } \\
\text { with violent or aggressive public } \\
\text { messages. }\end{array}$ \\
\hline $\begin{array}{l}\text { Chrono system (interconnections } \\
\text { among the child/adolescent and their } \\
\text { environments over time) }\end{array}$ & $\begin{array}{l}\text { Adolescent creating a view of their } \\
\text { personal world as one of aggression, } \\
\text { conflict, war, and fear. }\end{array}$ & $\begin{array}{l}\text { Plan family excursions outside Bosnia } \\
\text { and Herzegovina (to provide the family } \\
\text { with different perspectives), limit the } \\
\text { amount of TV news media viewed at } \\
\text { home, etc. }\end{array}$ \\
\hline
\end{tabular}




\section{Case vignette}

To better illustrate how the ecological model helps inform our clinical practice we present a case vignette, which demonstrates both individual interventions and the additional strategies listed in Table 2. Note that all case materials are disguised to protect patient privacy and confidentiality. The information is provided for illustrative purposes only and is not intended to direct how treatment should be provided in a particular case.

Samir is a 13-year-old boy who is currently in the seventh grade. Born in Germany, he moved with his mother to Tuzla in Bosnia and Herzegovina after his parents' divorce. At the time of his arrival in Tuzla, Samir did not speak the Bosnian language. After two years of attending a Bosnian school, Samir is still significantly behind in his Bosnian language skills and he speaks with a distinctive accent. Moreover, Samir had to change school three times over the past two years, due to academic problems as well as his physical and verbal aggression toward his peers and teachers. Despite Samir's obvious intellectual abilities, he has struggled to excel academically.

At home, Samir has a poor relationship with his 39-year-old mother, Aida, and they have frequent arguments. He is also verbally and physically aggressive toward his mother. Samir also exhibits suicidal tendencies. For example, during a previous argument, Samir attempted to jump out of the window.

Aida was only a teenager when she survived the Srebrenica genocide in July 1995. Along with her mother and brother, she witnessed several traumatic events in Srebrenica, including events in which children were killed by grenades. During this period, she was often hungry and fearful of Serbian soldiers entering Srebrenica. In addition, her father went missing during this period and she did not know if he was alive. Aida, her mother, and brother eventually fled Srebrenica in a convoy, and after an arduous journey that took them through Macedonia and Croatia, they ended up in Germany. During the five-month journey from Srebrenica to Germany, Aida and her family stayed in various refugee camps in which they were provided with food and shelter by various humanitarian aid organizations. In Germany, Aida took care of her family by working several jobs, such as a newspaper carrier and a restaurant waitress, while also attending school. Even though Aida did not speak German when she first moved to Germany, she still excelled in school. After a short relationship with a 
German man, they eventually married. Although the marriage was initially stable, it deteriorated soon after the birth of Samir. In fact, Aida stated that she experienced "emotional and physical abuse" from her husband, which eventually spilled over into his relationship with Samir. In one instance, he left Samir outside of the house all night as punishment. In another instance, he killed Samir's pet hamster in front of him because he had spilled some water on the table.

After 10 years of marriage, Aida decided to divorce her husband. She subsequently moved with Samir to Tuzla and found a job. However, she frequently visits Srebrenica, where her mother currently resides.

Aida has never received psychological assessments or psychotherapeutic services. To date, she states that Srebrenica is a "past that I do not want to talk about." Although Aida has never been formally evaluated for posttraumatic stress disorder (PTSD), Samir's clinician suspects that Aida most likely suffers from some type of anxiety disorder, due to her self-disclosed behaviors with intimate partners and her obsession with hygiene, which sometimes includes not allowing Samir to go to sleep until his room has been completely cleaned.

After her return to Tuzla, Aida formed a relationship with a man who became addicted to some "serious drugs." During this relationship, the atmosphere at home was rather chaotic, which included frequent arguments to which Samir was exposed. Over the 10-month relationship, Samir also experienced verbal and physical abuse by his mother's boyfriend. Although Aida is currently in a more supportive and peaceful relationship, the presence of a "stranger" at home makes Samir anxious. Also, Samir reports feeling "uneasy" when he watches TV news with his mother as she seems very upset whenever the news covers stories related to the war in the 1990s.

In addition to the aforementioned situations, Samir dealt with emotional and physical abuse by his peers in childcare and kindergarten while in Germany. As a result, he refused to go to school and he suffered from psychosomatic symptoms (e.g., vomiting and headaches). His mother eventually moved Samir to another school.

For Case conceptualization of Samir, based on the proposed ecological model, please refer to Table 2 . 


\section{Table 2. Case conceptualization of Samir based on the proposed ecological model}

\begin{tabular}{|c|c|c|}
\hline Levels of Ecology & Types of Stressors & $\begin{array}{l}\text { Treatments, Recommendations, and } \\
\text { Other Strategies (examples) }\end{array}$ \\
\hline $\begin{array}{l}\text { Samir is a 13-year-old adolescent male } \\
\text { (sex; cognitive factors; biological } \\
\text { mechanisms). }\end{array}$ & $\begin{array}{l}\text { Possible genetic predisposition to } \\
\text { anxiety; cognitive vulnerability to } \\
\text { anxiety. }\end{array}$ & $\begin{array}{l}\text { Both Samir and his mother Aida will be } \\
\text { introduced to the following: } \\
\text { Psychoeducation about PTSD; } \\
\text { relaxation techniques; coping strategies; } \\
\text { cognitive processing of reactions to } \\
\text { trauma; affect monitoring and emotion } \\
\text { regulation skills; construction of a } \\
\text { therapeutic trauma narrative; joint } \\
\text { parent-child sessions (Carrion and } \\
\text { Kletter, 2012). }\end{array}$ \\
\hline Microsystem & $\begin{array}{l}\text { Frequent outbursts between the mother } \\
\text { (with possible PTSD) and the } \\
\text { adolescent. }\end{array}$ & $\begin{array}{l}\text { Mother-adolescent therapy (i.e., joint } \\
\text { parent-child sessions). Provide the } \\
\text { mother with psychoeducation on PTSD } \\
\text { and relaxation techniques. }\end{array}$ \\
\hline $\begin{array}{l}\text { Mesosystem } \\
\text { (relationship among the microsystems) }\end{array}$ & $\begin{array}{l}\text { Interactions between the mother and } \\
\text { current boyfriend. The boyfriend's } \\
\text { presence causes Samir anxiety and } \\
\text { significant stress. Poor parental } \\
\text { interaction with the school and teachers. }\end{array}$ & $\begin{array}{l}\text { Family therapy that focuses on } \\
\text { processing emotions related to the } \\
\text { mother's PTSD. Arrange joint meetings } \\
\text { with a child psychologist, the mother, } \\
\text { and the teacher(s) in order to help with } \\
\text { Samir's school-related behavioral } \\
\text { problems and learning plans. }\end{array}$ \\
\hline Exosystem (public policy) & $\begin{array}{l}\text { Lack of resources in the community; } \\
\text { limited healthcare, etc. }\end{array}$ & $\begin{array}{l}\text { A child psychologist will advocate for } \\
\text { more support programs in order to help } \\
\text { other adolescents like Samir. }\end{array}$ \\
\hline $\begin{array}{l}\text { Macrosystem (culture; socio-economic } \\
\text { status, gender roles, etc.) }\end{array}$ & $\begin{array}{l}\text { Television, news, and media that focus } \\
\text { on ethnic hatred, continued threats of } \\
\text { war, and related conflicts. }\end{array}$ & $\begin{array}{l}\text { Psychologists, researchers, and } \\
\text { educators should serve as consultants to } \\
\text { the media in order to educate the public } \\
\text { on the effects of violent content. } \\
\text { Process emotions in individual/family } \\
\text { therapy related to viewing politicians } \\
\text { with violent/aggressive public } \\
\text { messages. }\end{array}$ \\
\hline $\begin{array}{l}\text { Chrono system (interconnections } \\
\text { between the adolescent and her } \\
\text { environment over time). }\end{array}$ & $\begin{array}{l}\text { Adolescent has created a view of the } \\
\text { world as one filled with aggression, } \\
\text { conflict, and fear, which has spread into } \\
\text { his interpersonal relationships. } \\
\text { Adolescent becomes stressed when } \\
\text { observing his mother react to news } \\
\text { regarding Srebrenica. }\end{array}$ & $\begin{array}{l}\text { Plan family excursions outside of } \\
\text { Bosnia and Herzegovina (to provide the } \\
\text { family with different perspectives) and } \\
\text { limit the amount of news media viewed } \\
\text { at home. } \\
\text { Over time, using the above strategies, } \\
\text { Samir's symptoms subsided. He is } \\
\text { currently performing better } \\
\text { academically and with significant } \\
\text { symptom reduction, and fewer } \\
\text { behavioral problems reported. }\end{array}$ \\
\hline
\end{tabular}




\section{Discussion}

The case study presented in this article highlighted the complexity and severity of the traumatic psychological effects of the war in Bosnia and Herzegovina on its citizens, including such effects on the generation born during or shortly after the war. By using a heuristic, in the form of an ecological analysis of human development (Bronfenbrenner, 1989), the present study proposed a framework for clinical research as well as intervention strategies for the adolescent children of war survivors who suffer from war-related trauma. The case conceptualization of the adolescent in this study aimed to demonstrate the application of this ecological framework in clinical practice.

The cultural, political, and societal realities in Bosnia and Herzegovina have greatly affected the population in general, and the children of war survivors in particular. Indeed, the transition from a state of war to peace is a long and continuous process in which the residual effects of the violent conflicts permeate society as a whole. In this case, the perpetrators of war crimes and their victims spoke the same language, they often lived close to one another before the conflict, and they even knew one another. For them, transitioning from a state of war to peace is even more complex. Moreover, the current political climate of Bosnia and Herzegovina has not significantly changed (e.g., Less, 2016; Kartsonaki, 2016; Tamkin, 2018) compared to the pre-war and wartime periods, thus making it more difficult for survivors suffering from war-related PTSD to recover and function in society. For example, Kartsonaki (2016) describes Bosnia and Herzegovina as being in "a dire political, social and economic deadlock" (Kartsonaki, 2016, p. 497). Further, Kartsonaki argues that continuous Republika Srpska's secessionist claims and referendum rhetoric continue to threaten the country's security. While the referendum is unlikely in the foreseeable future the mere existence of this rhetoric engenders a sense of insecurity (Kartsonaki). In the context of war-related trauma and PTSD, such rhetoric, especially when repeated almost consistently on the local news, could have an effect on people in general and on those who survived the war in Bosnia and Herzegovina in particular as such rhetoric communicates a realistic threat of future conflicts. 


\section{Conclusion}

In sum, the roles of psychologists and mental health providers should be expanded beyond the traditional focus on intrapsychic problems. Psychologists should also recognize interaction between their psychiatric symptoms and the larger systemic stressors that patients experience on a daily basis. As such, psychologists must also serve as advocates who urge local and state governments to provide more resources for psychosocial support. Finally, psychologists must focus on the larger context in which they collaborate with the patients' parents, teachers, and community members, all of whom directly affect the health and well-being of the patients themselves. 


\section{REFERENCES}

Awad, G. H., Kia-Keating, and Amer, M. M., (2019). A Model of Cumulative Racial-Ethnic trauma Among Americans of Middle Eastern and North Africa (MENA) Descent. American Psychologist, 74(1), 76-87.

Allen, B. (1996). Rape Warfare: The Hidden Genocide in BosniaHerzegovina and Croatia. Minneapolis, MN: University of Minnesota Press.

Bronfenbrenner, U. (1989). Ecological systems theory. In R. Vasta (Ed.), Annals of child development (Vol. 6, pp. 187-249). Greenwich, CT: JAI Press.

CID (2002). I Begged Them to Kill Me: Crime Against the Women of BosniaHerzegovina. Sarajevo: Center for Investigation and Documentation of the Association of Former Prison Camp Inmates of Bosnia-Herzegovina (CID).

Carrion, V.G., \& Kletter, H. (2012). Posttraumatic stress disorder: shifting toward a developmental framework. Child Adolescent Psychiatric Clinics of North America, 21, 573-591.

Dansby, V. S., \& Marinelli, R. P. (1999). Adolescent children of Vietnam combat veteran fathers: A population at risk. Journal of Adolescence, 22, 329-340.

Demeny, G. (2011). Factors of Socio-economic Uncertainty in the Bosnian War. MICROCON Research Working Paper 44, Brighton: MICROCON.

Herman, J. (1997). Trauma and recovery: The aftermath of violence from domestic abuse to political terror. New York: Basic Books.

Hoffman, M. A., and Kruczek, T. (2011). A Bioecological Model of Mass Trauma: Individual, Community, and Societal Effects. The Counseling Psychologist, 39(8), 1087-1127.

Gutman, R. (1993). A witness to Genocide. New York: Macmillan.

Kartsonaki, A. (2016). Twenty Years After Dayton: Bosnia-Herzegovina (Still) Stable and Explosive. Civil Wars, 18(4), 488-516. Westview. 
Less, T. (2016, December 20). Dysfunction in the Balkans: Can the PostYugoslav Settlement Survive? Foreign Affairs, Retrieved from https:/www.foreignaffairs.com/articles/bosnia-herzegovina/2016-12-20/ dysfunction-balkans

Meznaric, S. (1994). Gender as an Ethno-Marker: Rape, War, and Identity in the Former Yugoslavia. In V. M. Moghadam (Ed.), Identity Politics and Women: Cultural Reassertion and Feminism in International Perspective (pp. 76-97). Boulder, CO.

Mollica, R.F., McInnes, K., Sarajlić, N., Lavelle, J., Sarajlić, I., \& Massagli, M.P. (1999). Disability associated with psychiatric comorbidity and health status in Bosnian refugees living in Croatia. JAMA, 282, 433-439.

Mollica, R.F., Sarajlić, N., Chernoff, M., Lavelle, J., Vukovic, I. S., \& Massagli, M.P. (2001). Longitudinal study of psychiatric symptoms, disability, mortality, and emigration among Bosnian refugees. JAMA, 286, 546-554.

Mrvic-Petrovic, N. (2001). A brief history of the state of BosniaHerzegovina (from its origins to the 1995 Dayton peace accords). In V. Nikolic-Ristanovic (Ed.), Women, Violence and War: Wartime Victimization of Refugees in the Balkans. Budapest: Central European Press.

Nikolic-Ristanovic, V. (2000). Sexual Violence, in V. Nikolic-Ristanovic (ed.) Women, Violence and War: Wartime Victimization of Refugees in the Balkans. Budapest: Central European Press.

Oberschall, A. (2000). The manipulation of ethnicity: from ethnic cooperation to violence and war in Yugoslavia. Ethnic and Racial Studies, 23(6), 982-1001.

Rosenheck, R., \& Fontana, A. (1998). Transgenerational effects of abusive violence on the children of Vietnam combat veterans. Journal of Traumatic Stress, 11, 731-742.

Skjelsbæk, I. (2006). Victim and Survivor: Narrated Social Identities of Women Who Experienced Rape During the War in Bosnia-Herzegovina. Feminism \& Psychology, 16(4), 373-403. 
Schulz, P. M., Resick, P. A., Huber, L. C., \& Griffin, M. G. (2006). The effectiveness of cognitive processing therapy for PTSD with refugees in a community setting. Cognitive and Behavioral Practice, 13, 322-331.

Serdarevic, M. \& Chronister, K., M. (2005). Research with immigrant population: The application of an ecological framework to mental health research with immigrant populations. The International Journal of Mental Health Promotion, 7(2), 23-33.

Stiglmayer, A. (1994). The Rapes in Bosnia-Herzegovina. In A. Stiglmayer (Ed.), Mass Rape: The War Against Women in Bosnia-Herzegovina. Lincoln, NE and London: University of Nebraska Press.

Tabeau E, Bijak J. (2005). War-related deaths in the 1992-1995 armed conflicts in Bosnia and Herzegovina: a critique of previous estimates and recent results. European Journal of Population, 21, 187-215.

Tahirovic, S. (2018). Influence of Parental Divorce on Anxiety Level of Adolescents. In Contemporary Perspectives on Child and Education. Intech.

Tamkin, E. (2018, March 21). Bosnia is Teetering on the Precipice of a Political Crisis. Should the United States be trying to stop it? Foreign Policy, Retrieved from https://foreignpolicy.com/2018/03/21/bosnia-is-teetering-on-theprecipice-of-a-political-crisis-balkans-election-law-dodik/ 
